[Agr. Biol. Chem., Vol. 34, No. 12, p. 1870 1871, 1970]

\title{
Glutaric Acid, a New Precursor of Biotin Biosynthesis
}

Sir:

Many workers ${ }^{1 \sim 6)}$ have reported that pimelic acid participates in the biosynthesis of biotin as an important precursor since the nutritive requirement of Corynebacterium diphtheriae for pimelic acid was found by du Vigneaud $e t$ al. ${ }^{7}$ However, the study on the biosynthesis of biotin not via pimelic acid has not yet been reported.

In the course of investigation on the biosynthesis of biotin by microorganisms, we have found that the resting cells of some strains belonging to the genus Agrobacterium synthesized biotin-vitamers, mainly desthiobiotin, from glutaric acid, but not from pimelic acid. This communication briefly describes the facts that glutaric acid may be thought to be an essential precursor in the biosynthesis of biotin with Agrobacterium.

Bacteria used in this study were Agrobacterium tumefaciens IAM $1525, A$. radiobacter IAM 1526 and $A$. radiobacter IAM 1527. These bacteria were cultivated at $28^{\circ} \mathrm{C}$ for $24 \mathrm{hr}$ on a reciprocal shaker with the same medium as described previously. ${ }^{6}$ ) The harvested cells were suspended in $0.850^{\circ}$ sodium

1) L. D. Wright, E. L. Cresson, J. Valiant, D. E. Wolf and K. Folkers, J. Am. Chem. Soc., 76, 4160 (1954).

2) K. Ogata, T. Tochikura, S. Iwahara, S. Takasawa, K. Ikushima, A. Nishimura and M. Kikuchi, Agr. Biol. Chem., 29, 889 (1965).

3) H. L. Elford and L. D. Wright, Biochem. Biophys. Res. Commun., 10, 373 (1963).

4) M. A. Eisenberg, ibid., 8, 437 (1962).

5) A. Lezius, E. Ringelmann and F. Lynen, Biochem. Z., 336, 510 (1963).

6) S. Iwahara, T. Tochikura and K. Ogata, Agr. Biol. Chem., 29, 262 (1965).

7) V. du Vigneaud, K. Dittmer, E. Hague and B. Long, Science, 96, 186 (1942). chloride solution and then shaken at $28^{\circ} \mathrm{C}$ for $1 \mathrm{hr}$. After the starvation, the cells were harvested, washed twice and resuspended in the saline. The suspension was used in the experiment as resting cells preparation. The reaction was arrested by heating the mixture in a boiling water bath for $2 \mathrm{~min}$. Biotinvitamers synthesized in the reaction mixture were quantitatively determined by microbiological assays with Saccharomyces cerevisiae ${ }^{81}$ and Lactobacillus arabinosus. ${ }^{91}$ The bioautographic technique was also used to determine the sort of the vitamers.

TABLE I. EFFECT OF DICARBOXYLIC ACIDS ON THE BIOSYNTHESIS OF BIOTIN-VITAMERS BY Agrobacterium sp.

\begin{tabular}{|c|c|c|c|}
\hline \multirow{2}{*}{ Addition } & \multicolumn{3}{|c|}{$\begin{array}{c}\text { Biotin-vitamers synthesized }(\mu \mathrm{g} / \mathrm{ml}) \\
\text { by }\end{array}$} \\
\hline & $\begin{array}{c}A . \\
\text { tumefaciens } \\
\text { IAM } 1525\end{array}$ & $\begin{array}{c}\text { A. } \\
\text { radiobacter } \\
\text { IAM } 1526\end{array}$ & $\begin{array}{c}A . \\
\text { radiobacter } \\
\text { IAM } 1527\end{array}$ \\
\hline Oxalic acid & trace & trace & trace \\
\hline Malonic acid & $" 1$ & $"$ & $"$ \\
\hline Glutaric acid & 2.70 & 0.86 & 0.48 \\
\hline Adipic acid & trace & trace & trace \\
\hline Pimelic acid & - & $"$ & " \\
\hline Suberic acid & " & $\pi$ & " \\
\hline Azelaic acid & $"$ & $"$ & $"$ \\
\hline Sebacic acid & " & $r$ & " \\
\hline
\end{tabular}

Reaction mixture, containing about $80 \mathrm{mg}$ (as dry matter) of resting cells, $2 \mathrm{mg}$ of indicated compound and $200 \mu$ moles of Tris-maleate buffer, $\mathrm{pH} \mathrm{7.0,} \mathrm{in} \mathrm{a}$ total volume of $1 \mathrm{ml}$, was aerobically incubated for $5 \mathrm{hr}$.

8) E. E. Snell, R. E. Eakin and R. J. Williams, J. Am. Chem. Soc., 62, 175 (1940).

9) L. D. Wright and H. R. Skeggs, Proc. Soc. Expl. Biol. Med., 56, 95 (1944). 
As shown in Table I, glutaric acid was found to be essential for the biosynthesis of biotin-vitamers among dicarboxylic acids tested by all the three strains of Agrobacterium, while pimelic acid was not effective at all. Further investigation was carried out about the effect of amino acids and other compounds on the biosynthesis of biotin-vitamers. As shown in Table II, it was found that L-lysine was also

TABLE II. EFFeCt OF AMINo ACIDS ON THE BIOSYNTHESIS OF BIOTIN-VITAMERS BY Agrobacterium sp.

\begin{tabular}{|c|c|c|c|}
\hline \multirow[b]{2}{*}{ Addition } & \multicolumn{3}{|c|}{$\begin{array}{c}\text { Biotin-vitamers synthesized }(\mu \mathrm{g} / \mathrm{ml}) \\
\text { by }\end{array}$} \\
\hline & $\begin{array}{c}\text { A. } \\
\text { tumefaciens } \\
\text { IAM } 1525\end{array}$ & $\begin{array}{c}\text { A. } \\
\text { radiobacter } \\
\text { IAM } 1526\end{array}$ & $\begin{array}{c}\text { A. } \\
\text { radiobacier } \\
\text { IAM } 1527\end{array}$ \\
\hline L-Alanine & trace & 0.33 & trace \\
\hline L-Leucine & $" \prime$ & trace & 11 \\
\hline L-Glutamic acid & $" 1$ & 0.34 & " \\
\hline L-Aspartic acid & $"$ & trace & $" 1$ \\
\hline L-Lysine & 2.70 & 0.56 & 0.48 \\
\hline L-Arginine & trace & trace & trace \\
\hline LOrnithine & "f & $"$ & " \\
\hline L-Threonine & $\sim$ & " & $" 1$ \\
\hline L-Cysteine & $" \prime$ & $" 1$ & $"$ \\
\hline DL-Methione & $"$ & "' & - \\
\hline
\end{tabular}

Reaction mixture was the same as described in Table I except that $2 \mathrm{mg}$ of amino acid was added instead of dicarboxylic acid.

effective for the biosynthesis of the vitamers. L-Alanine and L-glutamic acid were somewhat effective for $A$. radiobacter IAM 1526 , but these amino acids were scarcely effective for other two strains. Figure 1 showed that the amount of biotin-vitamers synthesized in the reaction mixture increased with the increased concentration of glutaric acid or L-lysine till the concentration of 3 to $4 \mathrm{mg}$ per $\mathrm{ml}$. The relation of the these compounds in the biosynthesis of biotin-vitamers may be possible to explain with a bacterial metabolic pathway in which

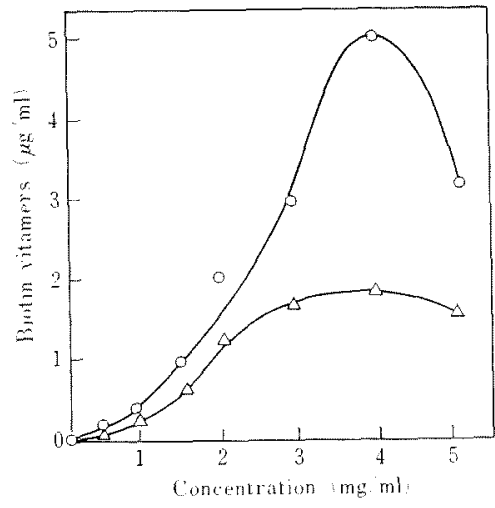

FIG. 1, Effect of Concentration on Glutaric Acid or L-Lysine.HCl on the Biosynthesis of BiotinVitamers by A. tumefaciens IAM 1525.

Reaction mixture, containing about $35 \mathrm{mg}$ (as dry matter) of resting cells, indicated amounts of glutaric acid or L-lysine. $\mathrm{HCl}$ and $200 \mu$ moles of Tris-maleate buffer, $\mathrm{pH} 7.0$, in a total volume of $1 \mathrm{ml}$, was aerobically incubated for $5 \mathrm{hr}$.

$\bigcirc-0$, glutaric acid was added; $\triangle-\triangle$, L-lysine. $\mathrm{HCL}$ was added.

L-lysine was degraded to glutaric acid. The main component of biotin-vitamers synthesized from glutaric acid or L-lysine by these Agrobacterium was characterized as desthiobiotin by the bioautography with $S$. cerevisiae. This was also confirmed from the observation that the vitamers could not be detected by microbiological assay with $L$. arabinosus.

The results described above show the presence of unique biosynthesis of biotin-vitamer from glutaric acid which has never so far been known, in Agrobacterium sp. The details of this work will be published in the near future.

Koichi Ogata

Yoshikazu IzUMI

Yoshiki TanI

Department of Agricultural Chemistry

Kyoto University, Kyoto

Received October 6, 1970 